\title{
High resistance of Panicum miliaceum L. to phenanthrene toxicity based on growth response and antioxidant system assessment
}

\author{
Sarieh TARIGHOLIZADEH ${ }^{1}$, Rouhollah MOTAFAKKERAZAD ${ }^{*}$, Seyed Yahya SALEHI-LISAR ${ }^{1}$, Elham \\ MOHAJEL KAZEMI ${ }^{1}$
}

Received December 04, 2020; accepted April 02, 2021.

Delo je prispelo 4. decembra 2020, sprejeto 2. aprila 2021.

\begin{abstract}
High resistance of Panicum miliaceum L. to phenanthrene toxicity based on growth response and antioxidant system assessment

Abstract: Polycyclic aromatic hydrocarbons are a group of organic pollutants influencing different aspects of plants physiology. Physiological responses associated with the impact of phenanthrene $(500,1000,1500,2000$ ppm) were analysed on Panicum miliaceum L. Seed germination was delayed in all treatments and $2000 \mathrm{ppm}$ of phenanthrene (PHE) significantly retarded the germination rate $(28 \%)$ compared to control. The results revealed after 30 day of cultivation, only 1500 and 2000 ppm of PHE had negative impacts on growth parameters as well as photosynthetic pigment contents. Plants exposed to 500 and $1000 \mathrm{ppm}$ of PHE showed an increase in the growth parameters without any symptoms of toxicity, indicating the high tolerance of seedlings to PHE. The activities of antioxidant enzymes were elevated in treated plants. In higher concentrations, $\mathrm{H}_{2} \mathrm{O}_{2}$ content also increased despite a reduction in malondialdehyde content. Furthermore, PHE had no effect on root phenol and shoot flavonoid contents and on shoot and root protein contents. Taken together, only higher concentrations of PHE triggered oxidative stress. It can be concluded PHE was not very toxic to $P$. miliaceum probably because of higher activity of antioxidant system involving in elimination of produced ROS even in plants treated by PHE higher concentrations.
\end{abstract}

Key words: polycyclic aromatic hydrocarbons; Panicum miliaceum; phenanthrene; physiological responses; toxicity
Velika odpornost navadnega prosa (Panicum miliaceum L.) na strupenost fenantrena temelji na rastnem odzivu in antioksidacijskem sistemu

Izvleček: Policiklični aromatski ogljikovodiki so skupina organskih onesnažil, ki vplivajo na različne vidike fiziologije rastlin. Fiziološki odzivi, povezani z vplivom fenantrena (PHE; $500,1000,1500,2000$ ppm) so bili analizirani na navadnem prosu (Panicum miliaceum L.). Kalitev semen je bila zapoznela pri vseh obravnavanjih, koncentracija fenantrena 2000 ppm je značilno zmanjšala hitrost kalitve $(28 \%)$ v primerjavi s kontrolo. Rezultati so pokazali, da se je negativni učinek fenantrena na rastne parametre in fotosintezena barvila $\mathrm{v}$ koncentracijah 1500 in 2000 ppm pokazal šele po 30 dnevih gojenja. Rastline, ki so bile izpostavljene koncentracijam 500 in 1000 ppm PHE so pokazale povečanje $\mathrm{v}$ rastnih parametrih, brez vsakršnih znakov zastrupitve, kar kaže na veliko tolerance teh rastlin na fenantren. $\mathrm{V}$ obravnavanih rastlinah se je povečala aktivnost antioksidacijskih encimov. Pri obravnavanjih $\mathrm{z}$ večjimi koncentracijami se je povečala tudi koncentracija $\mathrm{H}_{2} \mathrm{O}_{2}$, kljub zmanjšanju vsebnosti malondialdehida. Dodatno, PHE ni imel nobenega učinka na vsebnost fenolov $\mathrm{v}$ koreninah in flavonoidov $\mathrm{v}$ poganjkih, kot tudi ne na vsebnost beljakovin $\mathrm{v}$ koreninah in poganjkih. Zaključimo lahko, da fenantren ni bil zelo strupen za navadno proso, verjetno zaradi večje aktivnosti antioksidacijskega sistema, ki je preprečil tvorbo ROS, celo pri rastlinah obravnavanimi z večjimi koncentracijami PHE

Ključne besede: policiklični aromatski ogljikovodiki; Panicum miliaceum; fenantren; fiziološki odziv; strupenost

$1^{*}$ Department of Plant Sciences, Faculty of Natural Sciences, University of Tabriz, Tabriz, Iran

E-mail of the corresponding author: rmotafakker@tabrizu.ac.ir 


\section{INTRODUCTION}

Polycyclic aromatic hydrocarbons (PAHs) belong to persistent organic pollutants (POPs) consisting of 2-7 condensed aromatic rings that are arranged in various structural configurations. They have been detected in various concentrations in different environments. These pollutants are derived from either natural or anthropogenic activities mainly associated with industrialization and urbanization (Krzebietke et al., 2018; Pogorzelec \& Piekarska, 2018; Wiłkomirski et al., 2018). PAHs are mostly known for being highly toxic, mutagenic, teratogenic, and carcinogenic (Tian et al., 2019). PAHs hydrophobic nature leads to their accumulation and enrichment in soils, which is the reason for the necessity of the remediation of contaminated sites (Pretorius et al., 2018). Their physicochemical characteristics are low solubility in water, low vapour pressure, and highly lipophilicity which results in their high mobility in environment (IARC, 1983). The USEPA has categorized 16 mainly studied PAHs as priority pollutants with occurrence in environment (Mojiri et al., 2019). Phenanthrene (PHE), as one of the priority compounds presented in US-EPA list, represents a typical low molecular weight (LMW) $\mathrm{PAH}$ with three fused benzene rings that exists at high levels in PAH polluted environments (Fu et al., 2018). Increased environmental pollution and anthropological disturbances to ecosystems led to the study of abiotic stress responses in plants and subsequent concern about remediation of PAHs and ecosystem restoration strategies (Alkio et al., 2005).

Accumulation capacity and toxicity of PAHs in biota have resulted in a concern about their fate and transport in plants (Hamdi et al., 2007). Plants, as a dominant component of ecosystems, generally are first organisms exposed to the PAHs. They can uptake PAHs through the roots from contaminated soils and subsequently transfer them into shoots (Oguntimehin et al., 2010; Kummerová et al., 2013). There have been plenty of studies concerning the toxicity of PAHs on plants. It appears that all stages of plant growth and development can be influenced by PAHs, such as morphological, cytological, genetical, and metabolic disorders (Tomar \& Jajoo, 2014; Dupuy et al., 2016). Inhibition of seed germination, reduction in biomass production, induction of oxidative stress, and disruption in photosynthetic apparatus function are some proven effects of PAHs on plants (Li et al., 2008; Liu et al., 2009; Tomar \& Jajoo, 2014). A study carried out by Ahammed et al. (2012) has suggested that growth inhibition and biomass reduction by PAHs can be due to induction of oxidative stress. The oxidative stress induced by PAHs and its connection with morphological disorders has been previously asserted by other studies, such as a study accomplished via Arabidopsis thaliana (L.) Heynh. exposed to PHE (Alkio et al., 2005). Plant morphology has been regarded as important indicators for toxicity measurements in some PAHs researches (Sverdrup et al., 2003; Kummerová \& Kmentová, 2004; Tomar \& Jajoo, 2014). However, biochemical changes can precede the growth and morphological changes. A better understanding of PAHs' influence on plant metabolic processes would provide data that is required for phytotoxicity assessment of these contaminants as well as selection of potential plants for the PAH phytoremediation in contaminated soils.

Panicum miliaceum L., also known as proso millet, broomcorn millet, etc., is an annual crop with thermophilic and photophilic characteristics which can adapt to various types of soils. Due to the resistance of $P$. miliaceum to salt, drought, and alkali stress, as well as its short growth cycle, it is usually grown as a remediation crop in various adverse conditions (Habiyaremye et al., 2017; Na et al., 2019). The previous studies on P. miliaceum have primarily described its tolerance/resistance to biotic and abiotic stresses (Hu et al., 2009). It has been reported that P. miliaceum is more tolerant to salt stress than foxtail millet, wheat, maize, or rice (Dong \& Zheng, 2006; Liu et al., 2015). However, no report is available on the potential of P. miliaceum L. for evaluating its tolerance to PAHs and also its growth and physiological responses to PAHs' contamination. Considering the importance of this species as feed for livestock and birds and the subsequent entry of these compounds into the food chain, as well as a plant that is used directly in the human diet in some parts of the world (Sabir et al., 2011), this study was conducted to investigate the phytotoxicity of high concentrations of PHE on P. miliaceum. In other words, the evaluation of the biochemical and physiological responses of $P$. miliaceum plant and its resistance capability to PHE were the main purposes of this study.

\section{MATERIAL AND METHODS}

\subsection{PLANT CULTIVATION AND TREATMENT}

Experiment was carried out as a pot culture of plants using a completely randomized design with three replications for each treatment. Particular amounts of PHE were dissolved in ethanol and appreciate volume of PHE solution was added to perlite to give a final concentration of PHE (500, 1000, 1500 and, 2000 ppm). After thoroughly mixing, perlites were dried at room temperature $\left(22-25^{\circ} \mathrm{C}\right)$ to allow the ethanol evaporation for $72 \mathrm{~h}$. Treated perlites were subdivided into $100 \mathrm{~g}$ portions in 
plastic pots for plant cultivation. The aforesaid concentrations were selected due to the ineffectiveness of lower concentrations of PHE to plant based on initial screening experiments (Data not shown).

The seeds of $P$. miliaceum 'Pishahang' were purchased from Pakan Bazr (Isfahan, Iran) and stored at $4{ }^{\circ} \mathrm{C}$ until cultivation. Uniform and healthy seeds were selected and sterilized by soaking in $1 \%(\mathrm{v} / \mathrm{v})$ sodiumhypochlorite solution for 5 minutes, and rinsed thoroughly using sterile distilled water. Then, 20 disinfected seeds per pot (replicate) were planted in uncontaminated (control) and PHE-contained perlites. Then, they were germinated on watered perlites in a dark condition for three days at room temperature. Finally, pots with all germinated seeds were placed in growth chambers with controlled conditions $\left(25-30{ }^{\circ} \mathrm{C}, 16 / 8 \mathrm{~h} \mathrm{light/dark}\right.$ photoperiod, light intensity of $75 \mu \mathrm{mol} \mathrm{m} \mathrm{m}^{-2} \mathrm{~s}^{-1}$ provided by common day light fluorescent lamps, and relative humidity of $60 \%$ ) for four weeks. The water content of the pots was adjusted to $100 \%$ field capacity every two days using sterile distilled water. After 4 and 10 days, the water of pots was replaced with $50 \%$ and $100 \%$ Hoagland solution, respectively. Seed germination rate was recorded. The rate of seed germination was defined as the percentage of germinated seeds to the total number of seeds.

\subsection{HARVESTING OF PLANTS AND ASSAYS}

The experiment was conducted for 30 days, and then plants were harvested and divided into the roots and shoots. Some morphological and growth parameters (such as germination, dry and fresh mass, root and shoot length) were estimated in order to evaluation of eventual differences between treatments. Plant samples were completely washed with water, immediately dried on the towel paper, and transferred to $70{ }^{\circ} \mathrm{C}$ after determining of the fresh mass (FM). The dry mass (DM) of samples was measured after $72 \mathrm{~h}$. Three replicates of each root and shoot samples of different treatments were utilized for examination of biochemical and physiological parameters.

\subsection{MEASUREMENT OF PHOTOSYNTHETIC PIG- MENTS CONTENT}

The assessment of the photosynthetic pigment contents (chlorophyll a, b, total chlorophyll, and total carotenoids) was performed based on the method described by Hartmut (1987). In brief, a quantity of $0.1 \mathrm{~g}$ of fresh leaf samples was homogenized with $5 \mathrm{ml}$ of acetone using a mortar and pestle on ice bath. After 48 hours, mixtures were filtered using a number 42 Whatman filter paper and the absorbance of filtrates was recorded at 645 , 663 , and $470 \mathrm{~nm}$ by using a spectrophotometer (Analytic Jena, Specol 1500, Germany). The determined contents of chlorophyll a, b, total chlorophyll and carotenoids were expressed in $\mu \mathrm{g} \mathrm{g}^{-1} \mathrm{M}$.

\subsection{MEASUREMENT OF STRESS INDICATOR ME- TABOLITES}

\subsubsection{Malondialdehyde}

Malondialdehyde (MDA) content measured by a method described by Boominathan and Doran (2002). In order to preparation of extract, $0.1 \mathrm{~g}$ of plants fresh material was homogenate in trichloroacetic acid $0.1 \%$ (TCA, Merck, Germany) and then centrifuged at $10000 \mathrm{~g}$ for $5 \mathrm{~min}$. Then, $0.5 \mathrm{ml}$ of supernatants was mixed with $2 \mathrm{ml}$ of $20 \%$ TCA containing $0.5 \%$ of 2-thiobarbituric acid (TBA, Merck, Germany) and transferred to hot water for $30 \mathrm{~min}$ at $95^{\circ} \mathrm{C}$. Mixtures cooled immediately and centrifuged at $10000 \mathrm{~g}$ for $15 \mathrm{~min}$. Finally, the absorbance of supernatants was recorded at $532 \mathrm{~nm}$ and MDA concentration were calculated according to a standard curve prepared using 3,1,1,3-tetraethoxy propane (0-100 nM). MDA content expressed as $\mu \mathrm{mol} \mathrm{g}{ }^{-1} \mathrm{FM}$.

\subsubsection{Hydrogen peroxide}

Hydrogen peroxide $\left(\mathrm{H}_{2} \mathrm{O}_{2}\right)$ assay was carried out according to Harinasut et al. (2003). Briefly, $0.1 \mathrm{~g}$ of plant fresh tissue was homogenized in TCA $0.1 \%$ and centrifuged at $10000 \mathrm{~g}$ for $15 \mathrm{~min} .0 .5 \mathrm{ml}$ of supernatant was immediately mixed with $0.5 \mathrm{ml}$ of phosphate buffer (10 $\mathrm{mM}, \mathrm{pH}=7)$ and $1 \mathrm{ml}$ potassium iodide $(\mathrm{KI}, 1 \mathrm{mM})$ and left at ambient temperature for $15 \mathrm{~min}$. Then, the absorbance of extracts was recorded at $390 \mathrm{~nm}$. The content of $\mathrm{H}_{2} \mathrm{O}_{2}$ was calculated using a standard curve prepared by using different concentrations of $\mathrm{H}_{2} \mathrm{O}_{2}(0-120 \mu \mathrm{mol})$ and expressed as $\mu \mathrm{mol} \mathrm{g}^{-1} \mathrm{FM}$.

\subsection{TOTAL PROTEIN CONTENT AND ACTIVITY OF ANTIOXIDANT ENZYMES}

In order to preparation of extracts, $0.1 \mathrm{~g}$ of the plant fresh material was homogenized in phosphate-buffered solution (PBS, $50 \mathrm{mM}, \mathrm{pH}=7$ ) using mortar and pesthe on ice bath and then centrifuged at $10000 \mathrm{~g}$ for 10 $\min$ at $4{ }^{\circ} \mathrm{C}$. The supernatant was immediately used for quantification of the total soluble protein content using method described by Bradford (1976) as well as the activity of peroxidase (POD), Ascorbate peroxidase (APX), superoxide dismutase (SOD), and catalase (CAT). Each measurement was performed with three replications for each treatment. 
The activity of POD (EC 1.11.1.7) was assayed by the method of Obinger et al. (1997). One unit of POD activity was defined as the enzyme amount capable of oxidizing of $1 \mu \mathrm{M}$ guaiacol to tetraguaiacol per minute and the enzyme activity was expressed as $\mathrm{U} \mathrm{mg}^{-1}$ protein.

The activity of APX (EC 1.11.1.11) was assayed according to of Boominathan and Doran (2002). One unit of enzyme activity is considered as the amount of enzyme required for production of $1 \mu \mathrm{min}^{-1}$ of ascorbate. APX activity expressed as $\mathrm{U} \mathrm{mg}^{-1}$ protein.

SOD (EC 1.15.1.1) activity was acquired by determination of nitro-blue-tetrazolium (NBT) photoreduction inhibition rate by extracts (Winterbourn et al., 1976). One unit of enzyme activity is defined as the amount of enzyme that inhibits $50 \%$ of photochemical reduction of NBT. SOD activity was expressed as $\mathrm{U} \mathrm{mg}^{-1}$ protein.

CAT (E.C. 1.11.1.6) assay conducted by using the method described by Chance \& Maehly (1955). One unit of enzyme activity was considered as the amount of enzyme required for the decomposition of $1 \mu \mathrm{M} \mathrm{H}_{2} \mathrm{O}_{2}$ per min. The enzyme activity was expressed as $\mathrm{U} \mathrm{mg}^{-1}$ protein.

\subsection{QUANTIFICATION OF NONENZYMATIC ANTIOXIDANTS (TOTAL PHENOL, FLAVO- NOIDS AND ANTHOCYANIN CONTENTS)}

For measurement of total phenolic and flavonoid contents, $0.1 \mathrm{~g}$ of plant samples were homogenized in 5 $\mathrm{ml}$ methanol using mortar and pestle. Then, the homogenates were centrifuged at $10000 \mathrm{~g}$ for $5 \mathrm{~min}$ and supernatants used for the tests. Assessment of flavonoids content has been accomplished based on a reported method by Chang et al. (2002). Briefly, $1.5 \mathrm{ml}$ of methanol, $100 \mu \mathrm{l}$ of $10 \%$ aluminum chloride, $100 \mu \mathrm{l}$ of $1 \mathrm{M}$ potassium acetate, and $2.8 \mathrm{ml}$ of distilled water were added to 500 $\mu \mathrm{l}$ of each extract (supernatant). After 40 minutes, the absorbance was recorded at $415 \mathrm{~nm}$ compared to the control. Quercetin was used for the preparation of calibration curve (20-200 $\left.\mathrm{mg} \mathrm{l}^{-1}\right)$. The total flavonoid content of the extract was reported as milligram quercetin equivalents (QE) $\mathrm{g}^{-1} \mathrm{FM}$. The phenolic content has been evaluated by the method of Meda et al. (2005). $100 \mu \mathrm{l}$ of the methanolic extract and $100 \mu \mathrm{l}$ of Folin-Ciocalteu's reagent have been added to $2.8 \mathrm{ml}$ distilled water, mixed thoroughly, and maintained for $6 \mathrm{~min}$. Then, $2 \mathrm{ml}$ of $20 \%$ $(\mathrm{w} / \mathrm{v})$ sodium carbonate $\left(\mathrm{NaHCO}_{3}\right)$ was added and left at ambient temperature for 30 minutes in the dark. Finally, the absorbance was recorded at $720 \mathrm{~nm}$ by a spectrophotometer. The standard curve was prepared by using of different concentrations of gallic acid with the same procedure. The content of phenolics was calculated (mg $\mathrm{ml}^{-1}$ ) by the measured absorbance based on calibration line equivalent to the gallic acid (mg of $\mathrm{GA} \mathrm{g}^{-1}$ of FM) (Meda et al., 2005).

To measure the total anthocyanin content, $0.05 \mathrm{~g}$ of dried plant sample was pulverized with $5 \mathrm{ml}$ of hydrochloric acid containing $1 \%$ methanol in a porcelain mortar. The solution was kept in the refrigerator for 24 hours and then, centrifuged for 10 minutes at $10000 \mathrm{~g}$. The absorbance of supernatant was measured at 530 and $657 \mathrm{~nm}$ against the control (hydrochloric acid containing $1 \%$ methanol). Finally, the anthocyanin content was calculated using the following equation (Mita et al., 1997).

$$
A=A_{530}-\left(0.25 \times A_{657}\right)
$$

Where, A is absorbance of the solution (subscripts indicate the wavelength at which the absorbance is measured).

\subsection{DPPH RADICAL SCAVENGING ACTIVITY}

The method of Miliauskas et al. (2004) was used for DPPH radical scavenging capacity of plant samples. In order to, $0.1 \mathrm{~g}$ of plant fresh sample was extracted by 5 $\mathrm{ml}$ of methanol and then, centrifuged at $10000 \mathrm{~g}$ for 5 $\min$. The supernatant was used for the test. To conduct the assay, $100 \mu \mathrm{l}$ of extract was reached to $2 \mathrm{ml}$ volume using methanol and $2 \mathrm{ml} 0.0004 \mathrm{DPPH}$ methanolic solution was added. The mixture was immediately mixed and incubated for 30 minutes in the dark at ambient temperature. The absorbance of the solution was recorded at $517 \mathrm{~nm}$ against control (2 $\mathrm{ml} \mathrm{DPPH}$ and $2 \mathrm{ml}$ methanol) and radical scavenging activity was calculated using the following equation:

I $\%=($ A control - A sample $) / A$ control $\times 100$

Where, $\mathrm{A}$ is absorbance of the solution.

\subsection{DATA ANALYSIS}

The obtained data were statistically analyzed by oneway analysis of variance (ANOVA) using SPSS software (version 22) and expressed as mean \pm SD of three independent replications. Tukey's multiple range tests were applied for mean comparison and values of $p \leq 0.05$ were considered statistically significant. SPSS software was also applied to calculate the correlation coefficient (Pearson) between characteristics. Microsoft excel 2013 software was used for the preparation of figures. 


\section{RESULTS AND DISCUSSION}

\subsection{GERMINATION RATE}

Seed germination was delayed by all PHE treatments for one day and the germination rate was decreased significantly as the concentration of PHE raised to 2000 ppm in comparison with the control $(p<0.05)$. Lower concentrations $(500,1000 \mathrm{ppm})$ of PHE had no effect on germination rate (Figure 1). Generally, seed germination is one of the most sensitive processes in the plants, using as a bioindicator for evaluation of pollutants effects on plants. Prevention of seed germination is one of the obvious toxic influence of PAHs (Henner et al., 1999; Somtrakoon \& Chouychai, 2013) which has been frequently reported in plants such as soybean (Li et al., 2013), maize (Houshani et al., 2019), wheat (Wei et al., 2014), sunflower and alfalfa (Salehi-Lisar \& Deljoo, 2015). Probably, the deterioration of seed embryo by PAHs is a main reason for the inhibition of seed germination (Reynoso-Cuevas et al., 2008; Kummerová et al., 2012).

\subsection{GROWTH PARAMETERS}

Plants exposed to PHE were morphologically more erect and up-righted at all levels in comparison with the control plants which were almost lying. The effect of PHE on growth parameters were depended on the type of parameter, plant organs as well as PHE concentration. After 30 days, root length only decreased at the highest concentration (2000 ppm) of PHE. Shoot length showed a significant increase in plants treated by 500, 1000 and 1500 ppm of PHE $(p<0.05)$, but did not show a significant change at $2000 \mathrm{ppm}$ in comparison with the con- trol (Figure 2a). Shoot FM increased significantly at 1000 and $1500 \mathrm{ppm}$, but showed a significant decrease at 2000 ppm of PHE $(p<0.05)$. However, it had no notable increment at $500 \mathrm{ppm}$ (lowest level). Both 500 and 1000 ppm of PHE led to considerable increase in root FM, but 1500 and $2000 \mathrm{ppm}$ concentrations caused no significant enhancement $(p<0.05)$ (Figure $2 b)$. Root and shoot DM were not remarkably affected by PHE, except for shoot $\mathrm{DM}$ at $500 \mathrm{ppm}$ of PHE which increased significantly ( $p$ $<0.05$ ) (Figure 2c).

Our results showed that the highest treatment of PHE significantly increased fresh and dry weight ratios of root to shoot $(\mathrm{R} / \mathrm{S})(p<0.05)$ (Figure $2 \mathrm{~d}$ ).

Growth parameters such as plant height, biomass, and leaf area represent a function of plants' growth $(\mathrm{Li}$ et al., 2013). The reduction of the growth indices in the presence of PAHs has been demonstrated previously in plants such as rice ( $\mathrm{Li}$ et al., 2008), wheat (Tomar \& Jajoo, 2014; Salehi-Lisar \& Deljoo, 2015), maize and pea seedlings (Kummerová et al., 2012). In the mentioned studies, the applied concentrations of PAHs were mostly below $100 \mathrm{mg} \mathrm{kg}^{-1}$. Rice plants had good resistance to slightly higher concentrations of PAHs (100 and $200 \mathrm{mg}$ $\mathrm{kg}^{-1}$ of pyrene and PHE), while the addition of $400 \mathrm{mg}$ $\mathrm{kg}^{-1}$ of pyrene and PHE resulted in some negative impacts on this plant growth (Li et al., 2008). In our work, intriguingly, $P$. miliaceum plants not only grew without any symptoms of toxicity at 500 and $1000 \mathrm{ppm}$ of PHE, but also showed an increase in the growth parameters; indicating the high tolerance of $P$. miliaceum seedlings to PHE. Although the higher concentrations of PHE (1500 and $2000 \mathrm{ppm}$ ) reduced the germination rate of P. miliaceum seeds, it is presumed that $1500 \mathrm{ppm}$ is the highest concentration of PHE that $P$. miliaceum could tolerate

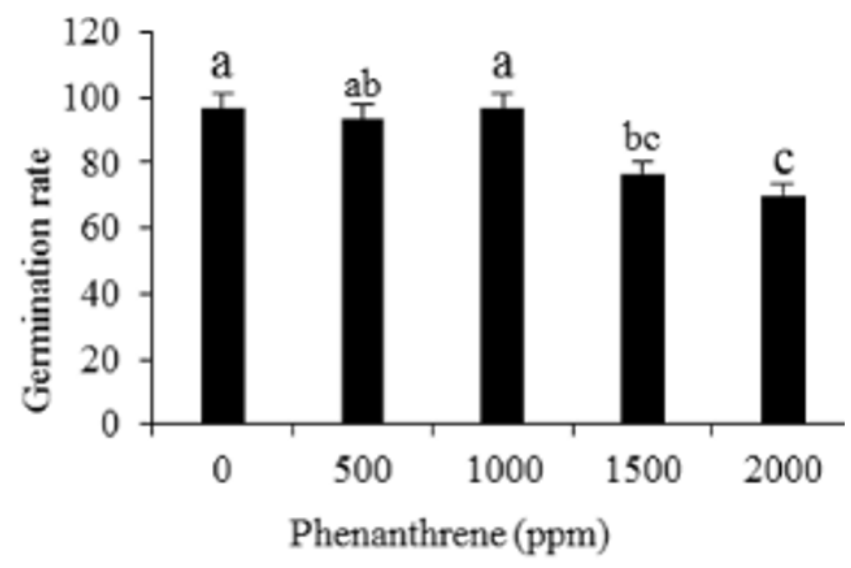

Figure 1: The effect of different concentrations of phenanthrene on seed germination rate of $P$. miliaceum. The level of confidence is $95 \%$ according to Tukey Test $(\mathrm{n}=3$ replicates) and error bars indicate SD. The same letters above the bars indicate no significant differences $(p<0.05)$. 

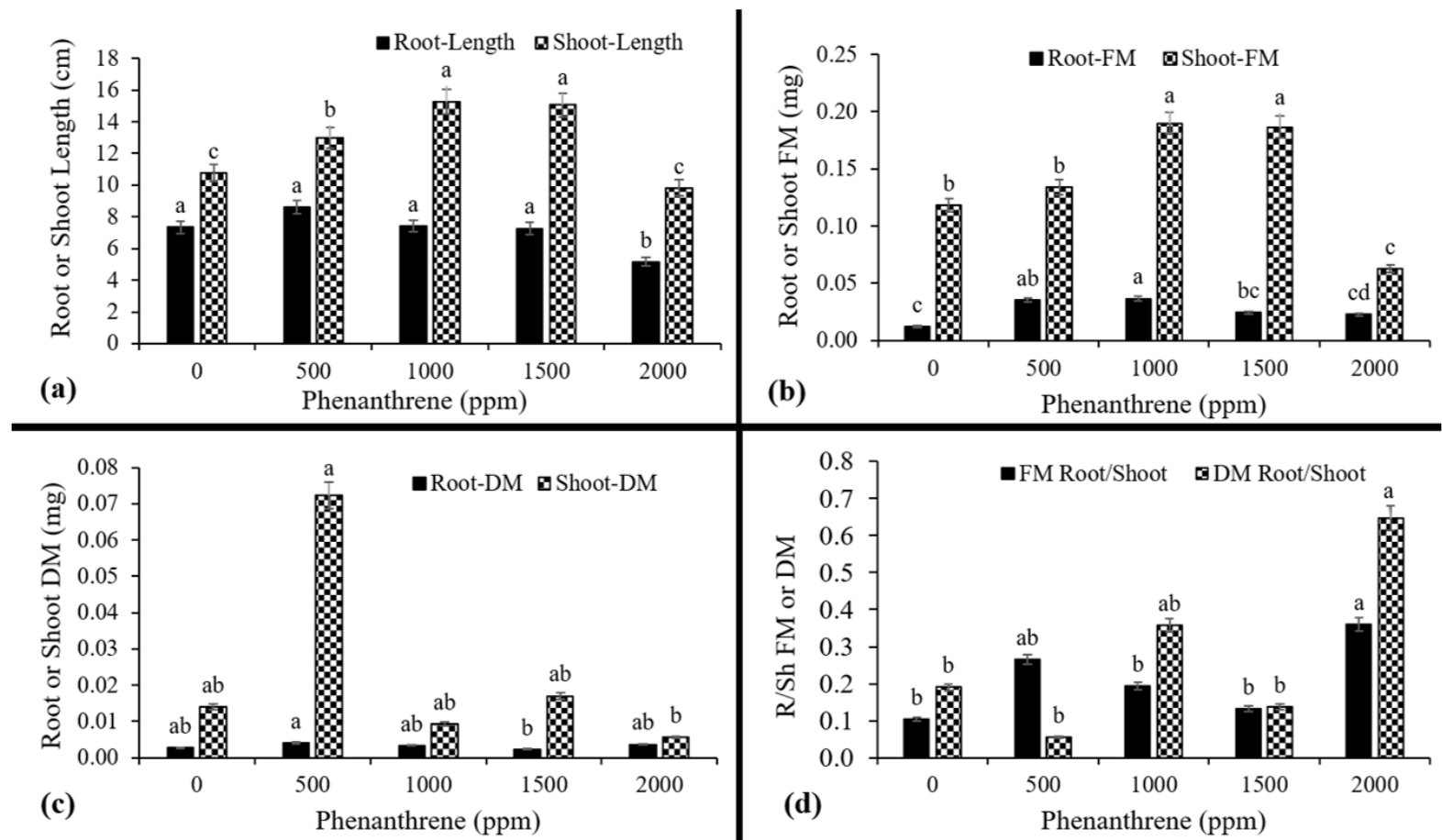

Figure 2: The effect of different concentrations of phenanthrene on P. miliaceum growth parameters a) root and shoot length, b) root and shoot fresh mass, c) root and shoot dry mass, and d) root to shoot fresh or dry mass ratios). The level of confidence is $95 \%$ according to Tukey Test $(\mathrm{n}=3$ replicates $)$ and error bars indicate SD. The same letters above the bars indicate no significant differences $(p<0.05)$.

without negative effects on growth. At this concentration the growth parameters are either increased or similar to control plants. However, at $2000 \mathrm{ppm}$ of PHE, shoot fresh mass was decreased by $50 \%$. In spite of this, P. miliaceum was able to survive in presence of $2000 \mathrm{ppm}$ of PHE during the testing period. The previous studies on P. miliaceum have also primarily described its resistance to various adverse conditions compared to similar plants from Poaceae family such as foxtail millet, wheat, maize, or rice (Dong \& Zheng, 2006; Hu et al., 2009; Liu et al., 2015).

The data showed a noticeable increase in $\mathrm{R} / \mathrm{S}$ ratio of $P$. miliaceum exposed to the highest concentration of PHE (2000 ppm). Literature review revealed that it is sometimes important for plants to allocate carbon resources to roots under stress condition such as PAHs toxicity. Plant biomass allocation, as a similar response induced by PAHs, was previously reported in Zea mays $\mathrm{L}$. and Phragmites australis (Cav.) Trin. ex Steud. (Nie et al., 2010; Dupuy et al., 2016). The same results with increasing R/S ratio were acquired in Medicago sativa L., clover and maize impressed by PAHs (Desalme et al., 2011; Dupuy et al., 2015; Salehi-Lisar \& Deljoo, 2015; Afegbua \& Batty, 2018). Altogether, the high $\mathrm{R} / \mathrm{S}$ ratio along with a significant decrease in root length in present work is a reason for the increased root thickness. The increment in root thickness was also confirmed for Pisum sativum L. and Z. mays plants treated with fluoranthene (Kummerová et al., 2013). In maize, PHE induced the extensive suberization of endo- and exodermises as a protective response by the plant for reduction of PHE penetration into roots (Dupuy et al., 2016).

\subsection{PHOTOSYNTHETIC PIGMENT CONTENTS}

Chlorophyll a, chlorophyll b and total chlorophyll were remarkably reduced in the plants treated by PHE compared to the control $(p<0.05)$. The lowest content of chlorophyll a and $\mathrm{b}$ were observed in the plants exposed to 1500 and $2000 \mathrm{ppm}$ of PHE, respectively (Figure 3 a \& b). Moreover, the increase in chlorophyll a/b ratio at all levels (especially $2000 \mathrm{ppm}$ ) of PHE in comparison with the control was statistically significant $(p<0.05)$ (Figure $3 c)$. Also, plants treated with $1500 \mathrm{ppm}$ of PHE showed a notable decline in carotenoids content in comparison with the control $(p<0.05)$ (Figure 3d). It appears that chlorophyll $\mathrm{b}$ was more affected by PHE, but carotenoids were less sensitive compared to chlorophylls (Figure 3). 


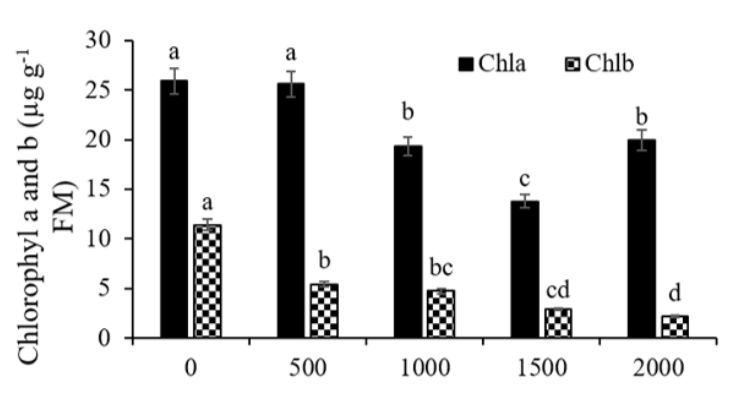

(a)

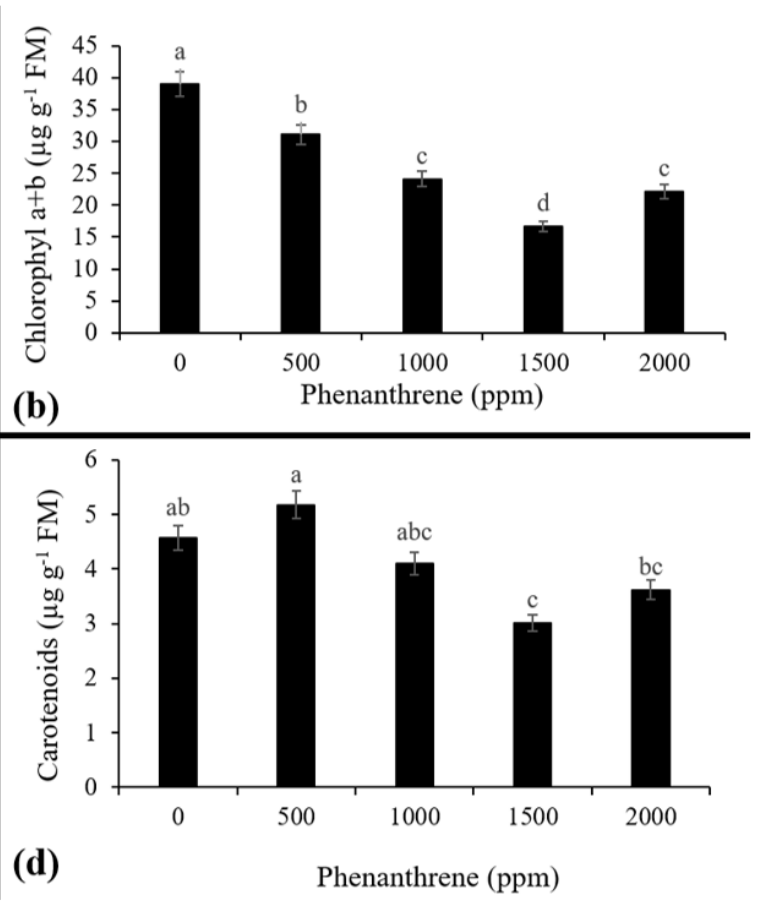

Figure 3: The effect of different concentrations of phenanthrene on photosynthetic pigments contents of $P$. miliaceum plants a) Chla and b, b) Chl a+b, c) Chla/b, and d) Carotenoids. The level of confidence is $95 \%$ according to Tukey Test ( $n=3$ replicates) and error bars indicate SD. The same letters above the bars indicate no significant differences $(p<0.05)$.

According to the results, photosynthetic processes in $P$. miliaceum were probably inhibited by PAH. This was demonstrated by the decrease of $\mathrm{Chl} \mathrm{a}, \mathrm{b}$ and total chlorophyll, and by the increase in the $\mathrm{Chl} \mathrm{a} / \mathrm{b}$ ratio at all treatments. However, based on the data obtained by present work, growth parameters generally increased or at least maintained at control level, and only the highest concentration of PHE led to reduction in some traits. Biomass production formerly regarded as a reliable external indicator of internal status of plant photosynthesis processes (Tomar \& Jajoo, 2014). Accordingly, it can be suggested that most likely changes in photosynthetic pigments content cannot be an appropriate indicator for assessing the sensitivity or resistance of $P$. miliaceum to PAHs contamination. This assumption was also supported by results of Salehi-Lisar \& Deljoo (2015). Reduction of photosynthetic pigments content have been reported in Arabidopsis thaliana and wheat plants treated by PHE and fluorene, respectively (Liu et al., 2009; Tomar \& Jajoo, 2014).

PAHs can cause oxidative stress in plants through induction of ROS production. In addition to structural role and light absorption, carotenoids can directly inactivate ROS or indirectly prevent the formation of ROS by quenching chlorophyll-elicitation (via xanthophyll cycle) and protect chloroplast membranes against oxidative stress (Ramel et al., 2012). Therefore, it seems that preservation of carotenoid content, especially at lower concentrations of PHE, has also contributed to plant tolerance for this pollutant.

\subsection{MALONDIALDEHYDE AND HYDROGEN PER- OXIDE CONTENTS}

A considerable dose-dependent elevation in $\mathrm{H}_{2} \mathrm{O}_{2}$ content was observed after 30 days of plants treatment by PHE. As compared to the control and the other PHE treatments, plant treated by $2000 \mathrm{ppm}$ of PHE showed a significant increase in root $\mathrm{H}_{2} \mathrm{O}_{2}$ content $(p<0.05) .1500$ and $2000 \mathrm{ppm}$ of PHE also caused a notable enhancement in shoot $\mathrm{H}_{2} \mathrm{O}_{2}$ content in comparison with the control plants $(p<0.05)$ (Figure 4a). $1000 \mathrm{ppm}$ of PHE led to a significant increase in root MDA content, compared with the control and other PHE treatments $(p<0.05)$. Also, a significant reduction in shoot MDA content was observed in plants treated by 1000, 1500 and $2000 \mathrm{ppm}$ compared to the control plants $(p<0.05)$ (Figure $4 \mathrm{~b})$. 

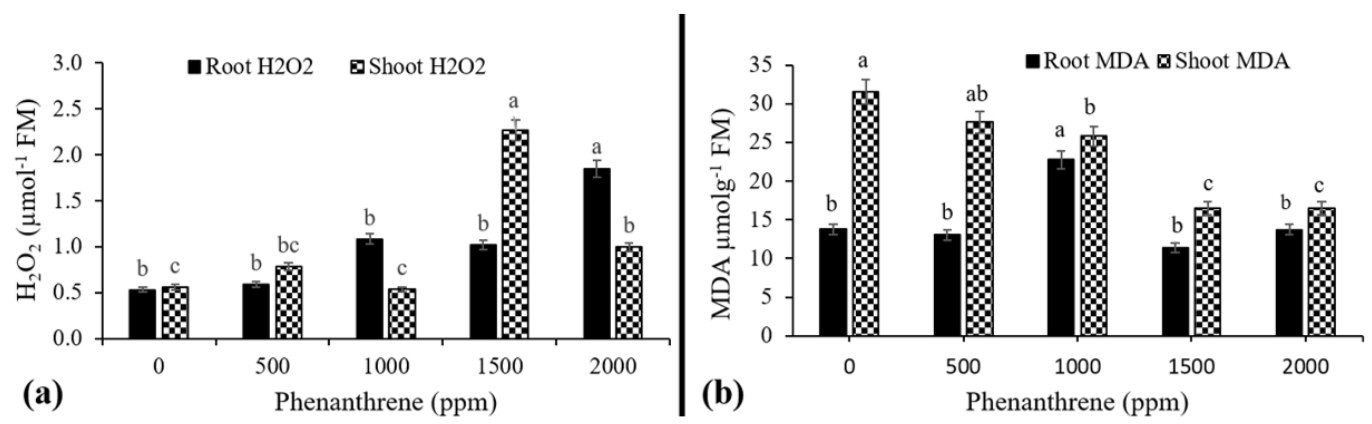

Figure 4: The effect of different concentrations of phenanthrene on $\mathrm{H}_{2} \mathrm{O}_{2}$ and MDA contents in the shoot and root of $P$. miliaceum plant. The level of confidence is $95 \%$ according to Tukey Test $(n=3$ replicates) and error bars indicate SD. The same letters above the bars indicate no significant differences $(p<0.05)$.

In general, with increment in PHE concentrations, $\mathrm{H}_{2} \mathrm{O}_{2}$ content was raised in the shoots and roots of $P$. miliaceum compared to the control plants. The increased amount of $\mathrm{H}_{2} \mathrm{O}_{2}$ was previously reported in the seedlings of wheat (Wei et al., 2014) and Arabidopsis thaliana (Liu et al., 2009). The highest amount of this trait was obtained at 1500 and $2000 \mathrm{ppm}$ of PHE for roots and shoots, respectively. However, the amount of MDA mounted to the highest level in $1000 \mathrm{ppm}$, and then dramatically dropped in higher concentrations of PHE in the roots $(p<0.05)$. In shoots, the amount of MDA was decreased compared to control. Taken together, given that even in non-stress conditions, there is always some $\mathrm{H}_{2} \mathrm{O}_{2}$ in plant tissues; here, it appears that the enhancement in $\mathrm{H}_{2} \mathrm{O}_{2}$ amount was not a big challenge for plant or its antioxidant system would be able scavenge produced $\mathrm{H}_{2} \mathrm{O}_{2}$. So, not only the content of MDA did not increase, it even decreased. According to the results, some growth parameters even increased at 1500 treatment. It can be suggested that at $2000 \mathrm{ppm}$ of PHE plant allocated more photosynthetic products to the root, for its thickening in order to create barriers against PHE penetration. Analysis of PHE concentration using HPLC also showed a decrease in the penetration of PHE into the root in plants treated by $2000 \mathrm{ppm}$ of PHE (Data not shown). In addition, a $50 \%$ reduction in shoot FM and increased root FM, along with a significant reduction in its length, also supports this point of view. So, it can be assumed that the antioxidant system of the root is strong enough and has been able to reduce the stress effects of PHE on plants. On the other hand, given that at high concentrations of PHE, the accumulation of MDA was lower in roots, it indicates that the potency of PHE stress in P. miliaceum is not considerable. Therefore, it can be concluded that MDA accumulation due to oxidative stress could not be a reliable marker for evaluation of the negative effect of PHE on P. miliaceum.

\subsection{TOTAL PROTEIN CONTENT}

Generally, PHE showed no significant effect on shoot and root protein content, however at the highest concentration of PHE a significant fall in shoot protein was observed $(p<0.05)$ (Figure 5). Therefore, the decrease in growth observed at this concentration of PHE may also be due in part to the plants' low capacity to produce protein under PHE toxicity. However, it is also possible that the transfer of more photosynthetic products to the root, and hence, the decrease in shoot growth, has led to a decrease in plants protein content. It is well known that plants need both carbohydrates and proteins to grow. In addition, root thickening may act as a barrier to efficient and effective uptake of nutrients and in turn lead to reduced growth. Salehi-Lisar \& Deljoo (2015) has also reported a decrease in shoot and root soluble protein in sunflower plants treated by fluorene.

\subsection{ANTIOXIDANT ENZYMES ACTIVITY}

The activity of antioxidant enzymes were assessed in P. miliaceum 30 days after seed cultivation. A dramatic increment was observed in the SOD, POD, CAT, and APX activities in plants treated by 1500 and $2000 \mathrm{ppm}$ of PHE $(p<0.05)$ in both shoots and roots $(p<0.05)$. However, there was often a significant difference between 1500 and 2000 treatments and generally the highest activity of these enzymes observed at $2000 \mathrm{ppm}$ of PHE, except for CAT activity in roots which was the highest in $1500 \mathrm{ppm}$ of PHE $(p<0.05)$ (Figure 6a-d). In general, antioxidant enzymes' activities in roots were higher than those in shoots of the plants (Figure 6a-d).

ROS accumulation is a main factor involving in toxicity induction due to direct or an indirect outcome of the PAHs exposure. ROS stimulates the activity of anti- 


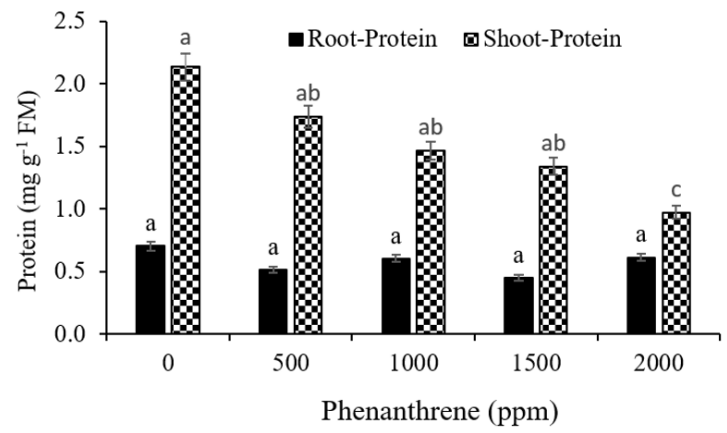

Figure 5: The effect of different concentrations of phenanthrene on protein content in the shoot and root of $P$. miliaceum plant. The level of confidence is $95 \%$ according to Tukey Test $(n=3$ replicates) and error bars indicate SD. The same letters above the bars indicate no significant differences $(p<0.05)$.
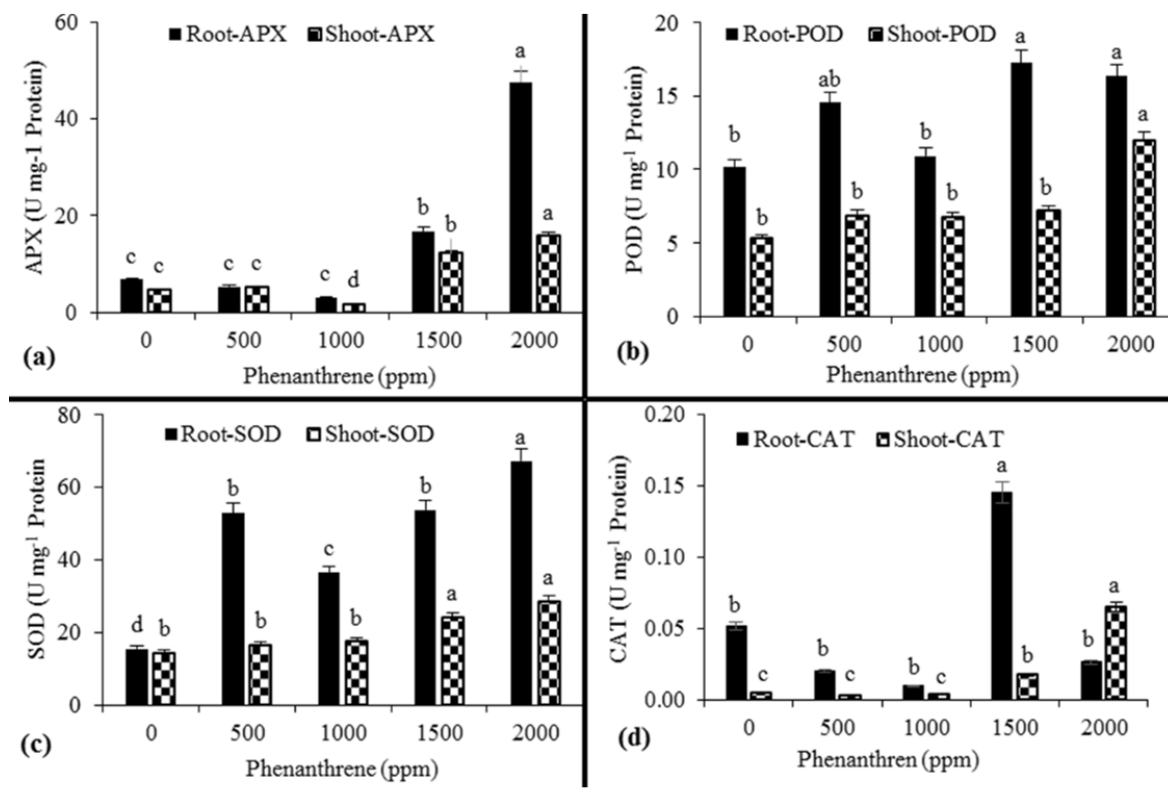

Figure 6: The effect of different concentrations of phenanthrene on antioxidant enzymes activity ( $\mathrm{U} \mathrm{mg}^{-1}$ protein) in the shoot and root of $P$. miliaceum plant. The level of confidence is $95 \%$ according to Tukey Test $(\mathrm{n}=3$ replicates) and error bars indicate $\mathrm{SD}$. The same letters above the bars indicate no significant differences $(p<0.05)$.

oxidant enzymes (e.g. SOD, POD, CAT, and APX). These enzymes are responsible for scavenging of produced ROS and their activities may indicate stress resistance potential of plants (Di Giulio, 1991). Increased activity of antioxidant enzymes by PAHs toxicity has been previously reported in maize (Houshani et al., 2019), wheat, sunflower, and alfalfa (Salehi-Lisar \& Deljoo, 2015), rice (Li et al., 2008) treated by fluorene, pyrene and PHE, respectively. In present study, higher activity of antioxidant enzymes in plants treated by 1500 and 2000 ppm of PHE is a result of induced ROS generation by PHE. However, PHE induced a concentration-dependent oxidative stress and the activity of antioxidant enzymes did not changed significantly in the lower PHE treatments. The analysis of correlation showed negative correlation coefficient between MDA content and antioxidant enzyme activities in shoot $\left(\mathrm{SOD} \mathrm{r} \mathrm{r}^{2}=-0.893\right.$, POD $\mathrm{r}^{2}=-0.590, \mathrm{CAT}^{2}=-0.705$, APX $\left.r^{2}=-0.740\right)$ and root (SOD $r^{2}=-0.771$, POD $r 2=$ $-0.717, \mathrm{CAT}^{2}=-0.451$, APX $\mathrm{r}^{2}=-0.688$ ) (Table 1). These findings indicate that antioxidant enzymes involved in ROS detoxification and plants resistance to oxidative stress are induced by PHE toxicity. Similar results were obtained for maize, alfalfa, sunflower, and wheat plants (Salehi-Lisar \& Deljoo, 2015). 


\subsection{NONENZYMATIC ANTIOXIDANTS}

PHE significantly increased anthocyanin and total phenol contents in shoots of plants treated by 500 and $2000 \mathrm{ppm}$ and $1500 \mathrm{ppm}$, respectively, compared to the control and other PHE treatments $(p<0.05)$. PHE had no effect on root anthocyanin and total phenol contents. However, flavonoids contents elevated at $2000 \mathrm{ppm}$ of PHE only in roots $(p<0.05)$ and no remarkable changes were detected in shoots (Table 2). This increment can be interpreted as a defence mechanism. Plants requiring a protective system involving enzymatic and non-enzymatic mechanisms for detoxification of ROS (Alscher et al., 1997). In this work, the amount of non-enzymatic antioxidants in shoot or root was raised probably in order to detoxification of accumulated oxidant metabolites at higher concentrations of PHE, along with increased antioxidant enzymes' activity, resulting in ROS scavenging and finally reduction in oxidative stress severity.

\subsection{DPPH RADICAL SCAVENGING ACTIVITY}

As seen in Figure 7, there were no significant changes in DPPH radical scavenging activity between treatments. 2, 2-diphenyl-1-picrylhydrazyl (DPPH) a molecule containing a stable free radical widely used to study the free radical-scavenging activity of natural antioxidants (Brand-Williams et al., 1995). According to the results of this work it can be concluded that studied plant was able to maintain their antioxidant capacity as to control plants.

Table 1: Statistical analysis for correlation between the activity of antioxidant enzyme and MDA content in the shoot and root of P. miliaceum plant.

\begin{tabular}{|c|c|c|c|c|c|c|c|c|c|c|}
\hline & $\begin{array}{l}\text { APX } \\
\text { Root }\end{array}$ & $\begin{array}{l}\text { APX } \\
\text { Shoot }\end{array}$ & $\begin{array}{l}\text { SOD } \\
\text { root }\end{array}$ & $\begin{array}{l}\text { SOD } \\
\text { Shoot }\end{array}$ & $\begin{array}{l}\text { POD } \\
\text { Root }\end{array}$ & $\begin{array}{l}\text { POD } \\
\text { Shoot }\end{array}$ & $\begin{array}{l}\text { CAT } \\
\text { Root }\end{array}$ & $\begin{array}{l}\text { CAT } \\
\text { Shoot }\end{array}$ & $\begin{array}{l}\text { MDA } \\
\text { Root }\end{array}$ & $\begin{array}{l}\text { MDA } \\
\text { Shoot }\end{array}$ \\
\hline MDA Shoot & $0.688^{* *}-$ & $0.740^{* *}$ & $0.771^{* *}-$ & $0.893^{* *}-$ & $0.717^{* *}$ & $0.590^{*}-$ & $0.451^{\mathrm{ns}}$ & $0.705^{* *}-$ & $0.192^{\text {ns }}$ & 1 \\
\hline MDA Root & $0.304^{\text {ns }}$ & $0.563^{*}-$ & $0.299^{\text {ns }}$ & $0.142^{\text {ns }}$ & $0.532^{*}-$ & $0.152^{\text {ns }}$ & $0.490^{\text {ns }}$ & $0.254^{\text {ns }}-$ & 1 & \\
\hline CAT Shoot & $0.978^{* *}$ & $0.875^{* *}$ & $0.679^{* *}$ & $0.801^{* *}$ & $0.527^{*}$ & $0.784^{*}$ & $0.022^{\text {ns }}$ & 1 & & \\
\hline CAT Root & $0.041^{\text {ns }}$ & $0.196^{\mathrm{ns}}$ & $0.074^{\text {ns }}$ & $0.238^{\text {ns }}$ & $0.397^{\text {ns }}$ & $0.130^{\text {ns }}$ & 1 & & & \\
\hline POD Shoot & $0.688^{* *}$ & $0.733^{* *}$ & $0.791^{* *}$ & $0.747^{\star *}$ & $0.538^{*}$ & 1 & & & & \\
\hline POD Root & $0.554^{*}$ & $0.767^{* *}$ & $0.816^{* *}$ & $0.730^{* *}$ & 1 & & & & & \\
\hline SOD Shoot & $0.797^{* *}$ & $0.767^{* *}$ & $0.812^{* *}$ & 1 & & & & & & \\
\hline SOD Root & $0.641^{*}$ & $0.772^{* *}$ & 1 & & & & & & & \\
\hline APX Root & $0.873^{* *}$ & 1 & & & & & & & & \\
\hline APX Shoot & 1 & & & & & & & & & \\
\hline
\end{tabular}

Notes: ${ }^{\star *}$ Correlation is significant at 0.01 levels, ${ }^{\star}$ Correlation is significant at 0.05 levels, ns correlation is not significant.

Table 2: The effect of the different concentrations of phenanthrene on phenol (mg GAE $\left.\mathrm{g}^{-1} \mathrm{FM}\right)$, flavonoids (mg QE $\left.\mathrm{g}^{-1} \mathrm{FM}\right)$ and anthocyanin (mg QE g $\left.{ }^{-1} \mathrm{FM}\right)$ contents in the shoot and root of $P$. miliaceum plant.

\begin{tabular}{|c|c|c|c|c|c|c|}
\hline \multirow{2}{*}{$\begin{array}{l}\text { Phenanthrene } \\
(\mathrm{ppm})\end{array}$} & \multicolumn{3}{|l|}{ Root } & \multicolumn{3}{|l|}{ Shoot } \\
\hline & Phenol & Flavonoids & Anthocyanin & Phenol & Flavonoids & Anthocyanin \\
\hline 0 & $2.93^{\mathrm{a}} \pm 0.17$ & $0.27^{\mathrm{b}} \pm 0.00$ & $0.03^{\mathrm{a}} \pm 0.01$ & $0.73^{b} \pm 0.32$ & $1.10^{\mathrm{a}} \pm 0.07$ & $0.18^{\mathrm{b}} \pm 0.17$ \\
\hline 500 & $3.03^{\mathrm{a}} \pm 0.03$ & $0.27^{\mathrm{b}} \pm 0.00$ & $0.05^{\mathrm{a}} \pm 0.02$ & $1.17^{\mathrm{b}} \pm 0.99$ & $1.30^{\mathrm{a}} \pm 0.05$ & $0.50^{\mathrm{a}} \pm 0.17$ \\
\hline 1000 & $1.95^{\mathrm{a}} \pm 0.58$ & $0.28^{\mathrm{b}} \pm 0.00$ & $0.04^{\mathrm{a}} \pm 0.01$ & $1.22^{\mathrm{b}} \pm 0.16$ & $1.20^{\mathrm{a}} \pm 0.04$ & $0.16^{\mathrm{b}} \pm 0.17$ \\
\hline 1500 & $2.07^{\mathrm{a}} \pm 1.47$ & $0.27^{\mathrm{b}} \pm 0.00$ & $0.05^{\mathrm{a}} \pm 0.01$ & $7.85^{\mathrm{a}} \pm 0.26$ & $1.04^{\mathrm{a}} \pm 0.20$ & $0.15^{\mathrm{b}} \pm 0.17$ \\
\hline 2000 & $2.06^{\mathrm{a}} \pm 0.29$ & $0.30^{\mathrm{a}} \pm 0.01$ & $0.02^{\mathrm{a}} \pm 0.00$ & $1.03^{\mathrm{b}} \pm 0.12$ & $1.14^{\mathrm{a}} \pm 0.06$ & $0.39^{\mathrm{a}} \pm 0.06$ \\
\hline
\end{tabular}

The data represent the mean of three replications \pm SD and similar upper case letters indicates no significant difference at $p<0.05$. 


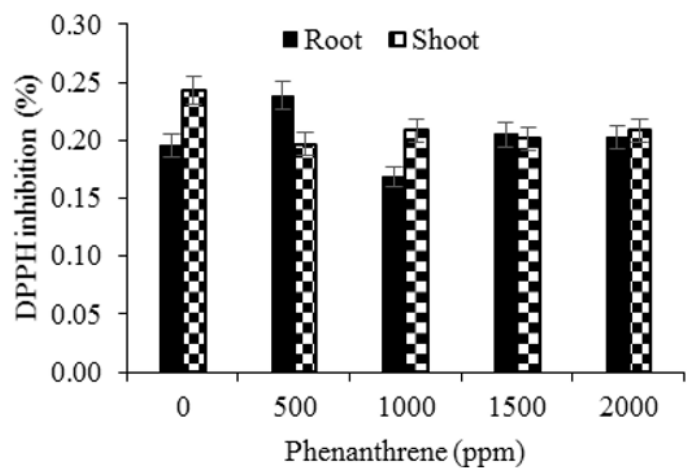

Figure 7: The effect of different concentrations of phenanthrene on DPPH radical scavenging activity in the shoot and root of $P$. miliaceum plant. The level of confidence is $95 \%$ according to Tukey Test ( $\mathrm{n}=3$ replicates) and error bars indicate SD.

\section{CONCLUSIONS}

The measurements of some morphological parameters as well as cellular responses in the forms of enzymatic and non-enzymatic antioxidants' activities in Panicum miliaceum exposed to phenanthrene have been main objectives of presented work. PHE had a negative impact on germination rate, growth and pigment content of $P$. miliaceum only at higher concentrations (1500 and 2000 $\mathrm{ppm})$. Therefore, in comparison to other studied plants $P$. miliaceum showed relatively very high tolerance to PHE toxicity, The results also showed a noticeable increment in antioxidant system activity due to the toxicity caused by PHE at higher concentrations as well as a significant elevation in non-enzymatic antioxidant contents that can be explained as a probable contributory system to the enzymes in order to ROS detoxifying. Taken all together, the antioxidant system of $P$. miliaceum was probably strong enough to reduce toxicity of produced ROS in significant amount, thus plant survived even in higher concentrations of PHE. It would be worthwhile to examine the capability of this plant for phytoremediation purposes through further research.

\section{ACKNOWLEDGMENT}

The authors thank the Research Affairs of University of Tabriz for financial and other supports.

\section{REFERENCES}

Afegbua, S. L., \& Batty, L. C. (2018). Effect of single and mixed polycyclic aromatic hydrocarbon contamination on plant biomass yield and PAH dissipation during phytoremediation. Environmental Science and Pollution Research, 25(19), 18596-18603. https://doi.org/10.1007/s11356-018-1987-1

Ahammed, G. J., Yuan, H. L., Ogweno, J. O., Zhou, Y. H., Xia, X. J., Mao, W. H., ... \& Yu, J. Q. (2012). Brassinosteroid alleviates phenanthrene and pyrene phytotoxicity by increasing detoxification activity and photosynthesis in tomato. Chemosphere, 86(5), 546-555. https://doi.org/10.1016/j.chemosphere.2011.10.038

Alkio, M., Tabuchi, T. M., Wang, X., \& Colon-Carmona, A. (2005). Stress responses to polycyclic aromatic hydrocarbons in Arabidopsis include growth inhibition and hypersensitive response-like symptoms. Journal of Experimental Botany, 56(421), 2983-2994. https://doi.org/10.1093/jxb/ eri295

Alscher, R. G., Donahue, J. L., \& Cramer, C. L. (1997). Reactive oxygen species and antioxidants: relationships in green cells. Physiologia Plantarum, 100(2), 224-233. https://doi. org/10.1111/j.1399-3054.1997.tb04778.x

Boominathan, R., \& Doran, P. M. (2002). Ni-induced oxidative stress in roots of the Ni hyperaccumulator, Alyssum bertolonii. New Phytologist, 156(2), 205-215. https://doi. org/10.1046/j.1469-8137.2002.00506.x

Brand-Williams, W., Cuvelier, M. E., \& Berset, C. L. W. T. (1995). Use of a free radical method to evaluate antioxidant activity. LWT-Food Science and Technology, 28(1), 25-30. https://doi.org/10.1016/S0023-6438(95)80008-5

Chance, B., \& Maehly, A. C. (1955). [136] Assay of catalases and peroxidases. https://doi.org/10.1002/9780470110171.ch14

Chang, C. C., Yang, M. H., Wen, H. M., \& Chern, J. C. (2002). Estimation of total flavonoid content in propolis by two complementary colorimetric methods. Journal of Food and Drug Analysis, 10(3). https://doi.org/10.38212/22246614.2748 
Desalme, D., Binet, P., Epron, D., Bernard, N., Gilbert, D., Toussaint, M. L., ... \& Chiapusio, G. (2011). Atmospheric phenanthrene pollution modulates carbon allocation in red clover (Trifolium pratense L.). Environmental Pollution, 159(10), 2759-2765. https://doi.org/10.1016/j.envpol.2011.05.015

Di Giulio, R. T. (1991). Indices of oxidative stress as biomarkers for environmental contamination. In Aquatic Toxicology and Risk Assessment: Fourteenth Volume. ASTM International. https://doi.org/10.1520/STP23561S

Dong, Y.C., Zheng, D. S. (2006). Crops and their wild relatives in China.

Dupuy, J., Leglize, P., Vincent, Q., Zelko, I., Mustin, C., Ouvrard, S., \& Sterckeman, T. (2016). Effect and localization of phenanthrene in maize roots. Chemosphere, 149, 130-136. https://doi.org/10.1016/j.chemosphere.2016.01.102

Dupuy, J., Ouvrard, S., Leglize, P., \& Sterckeman, T. (2015). Morphological and physiological responses of maize (Zea mays) exposed to sand contaminated by phenanthrene. Chemosphere, 124, 110-115. https://doi.org/10.1016/j.chemosphere.2014.11.051

Habiyaremye, C., Barth, V., Highet, K., Coffey, T., \& Murphy, K. M. (2017). Phenotypic responses of twenty diverse proso millet (Panicum miliaceum L.) accessions to irrigation. Sustainability, 9(3), 389. https://doi.org/10.3390/su9030389

Hamdi, H., Benzarti, S., Manusadžianas, L., Aoyama, I., \& Jedidi, N. (2007). Bioaugmentation and biostimulation effects on PAH dissipation and soil ecotoxicity under controlled conditions. Soil Biology and Biochemistry, 39(8), 19261935. https://doi.org/10.1016/j.soilbio.2007.02.008

Harinasut, P., Poonsopa, D., Roengmongkol, K., \& Charoensataporn, R. (2003). Salinity effects on antioxidant enzymes in mulberry cultivar. Science Asia, 29(2), 109-113. https:// doi.org/10.2306/scienceasia1513-1874.2003.29.109

Hartmut, K. L. (1987). Chlorophylls and carotenoids: Pigments of photosynthetic biomembranes. In R. D. Lester Packer (Ed.). Methods in enzymology. New York, NY, Academic Press, pp 350-382. http://dx.doi.org/10.1016/00766879(87)48036-1

Henner, P., Schiavon, M., Druelle, V., \& Lichtfouse, E. (1999). Phytotoxicity of ancient gaswork soils. Effect of polycyclic aromatic hydrocarbons (PAHs) on plant germination. Organic Geochemistry, 30(8), 963-969. https://doi. org/10.1016/S0146-6380(99)00080-7

Houshani, M., Salehi-Lisar, S. Y., Movafeghi, A., \& Motafakkerazad, R. (2019). Growth and antioxidant system responses of maize (Zea mays L.) seedling to different concentration of pyrene in a controlled environment. Acta agriculturae Slovenica, 113(1), 29-39. http://dx.doi.org/10.14720/ aas.2019.113.1.03

Hu, X., Wang, J., Lu, P., \& Zhang, H. (2009). Assessment of genetic diversity in broomcorn millet (Panicum miliaceum L.) using SSR markers. Journal of Genetics and Genomics, 36(8), 491-500. https://doi.org/10.1016/S1673-8527(08)60139-3

International Agency for Research on Cancer. (1983). Polynuclear aromatic compounds, part 1, chemical, environmental, and experimental data. IARC Monographs on the Evaluation of the Carcinogenic Risk of Chemicals to Man, IARC Scientific Publications, 32, 33-451.
Krzebietke, S. J., Wierzbowska, J., Żarczyński, P. J., Sienkiewicz, S., Bosiacki, M., Markuszewski, B., ... \& Mackiewicz-Walec, E. (2018). Content of PAHs in soil of a hazel orchard depending on the method of weed control. Environmental Monitoring and Assessment, 190(7), 422. https://doi. org/10.1007/s10661-018-6812-2

Kummerová, M., \& Kmentová, E. (2004). Photoinduced toxicity of fluoranthene on germination and early development of plant seedling. Chemosphere, 56(4), 387-393. https://doi. org/10.1016/j.chemosphere.2004.01.007

Kummerová, M., Zezulka, Š., Babula, P., \& Váňová, L. (2013). Root response in Pisum sativum and Zea mays under fluoranthene stress: morphological and anatomical traits. Chemosphere, 90(2), 665-673. https://doi.org/10.1016/j. chemosphere.2012.09.047

Kummerová, M., Zezulka, Š., Váňová, L., \& Fišerová, H. (2012). Effect of organic pollutant treatment on the growth of pea and maize seedlings. Open Life Sciences, 7(1), 159-166. https://doi.org/10.2478/s11535-011-0081-1

Li, J. H., Gao, Y., Wu, S. C., Cheung, K. C., Wang, X. R., \& Wong, M. H. (2008). Physiological and biochemical responses of rice (Oryza sativa L.) to phenanthrene and pyrene. International Journal of Phytoremediation, 10(2), 106-118. https:// doi.org/10.1080/15226510801913587

Li, Q., Lu, Y., Shi, Y., Wang, T., Ni, K., Xu, L., ... \& Giesy, J. P. (2013). Combined effects of cadmium and fluoranthene on germination, growth and photosynthesis of soybean seedlings. Journal of Environmental Sciences, 25(9), 1936-1946. https://doi.org/10.1016/S1001-0742(12)60264-2

Liu, H., Weisman, D., Ye, Y. B., Cui, B., Huang, Y. H., ColónCarmona, A., \& Wang, Z. H. (2009). An oxidative stress response to polycyclic aromatic hydrocarbon exposure is rapid and complex in Arabidopsis thaliana. Plant Science, 176(3), 375-382. https://doi.org/10.1016/j.plantsci.2008.12.002

Liu, M., Qiao, Z., Zhang, S., Wang, Y., \& Lu, P. (2015). Response of broomcorn millet (Panicum miliaceum L.) genotypes from semiarid regions of China to salt stress. The Crop Journal, 3(1), 57-66. https://doi.org/10.1016/j.cj.2014.08.006

Mann, T. (1984). A rapid and sensitive method for the quantization of microgram quantities of protein utilizing the principle of protein dye-binding. Annals of Biochemistry, 72, 248-254. https://doi.org/10.1016/0003-2697(76)90527-3

Miliauskas, G., Venskutonis, P. R., \& Van Beek, T. A. (2004). Screening of radical scavenging activity of some medicinal and aromatic plant extracts. Food Chemistry, 85(2), 231237. https://doi.org/10.1016/j.foodchem.2003.05.007

Mita, S., Murano, N., Akaike, M., \& Nakamura, K. (1997). Mutants of Arabidopsis thaliana with pleiotropic effects on the expression of the gene for $\beta$-amylase and on the accumulation of anthocyanin that are inducible by sugars. The Plant Journal, 11(4), 841-851. https://doi.org/10.1046/j.1365313X.1997.11040841.x

Mojiri, A., Ziyang, L., Tajuddin, R. M., Farraji, H., \& Alifar, N. (2016). Co-treatment of landfill leachate and municipal wastewater using the ZELIAC/zeolite constructed wetland system. Journal of Environmental Management, 166, 124130. https://doi.org/10.1016/j.jenvman.2015.10.020

Na, X., Cao, X., Ma, C., Ma, S., Xu, P., Liu, S., ... \& Qiao, Z. 
(2019). Plant stage, not drought stress, determines the effect of cultivars on bacterial community diversity in the rhizosphere of broomcorn millet (Panicum miliaceum L.). Frontiers in Microbiology, 10, 828. https://doi.org/10.3389/ fmicb.2019.00828

Obinger, C., Maj, M., Nicholls, P., \& Loewen, P. (1997). Activity, Peroxide Compound Formation, and Heme d Synthesis in Escherichia coli HPII Catalase. Archives of Biochemistry and Biophysics, 342(1), 58-67. https://doi.org/10.1006/ abbi.1997.9988

Oguntimehin, I., Eissa, F., \& Sakugawa, H. (2010). Negative effects of fluoranthene on the ecophysiology of tomato plants (Lycopersicon esculentum Mill): Fluoranthene mists negatively affected tomato plants. Chemosphere, 78(7), 877-884. Chemosphere, 78(7), 877-884. https://doi.org/10.1016/j. chemosphere.2009.11.030

Pogorzelec, M., \& Piekarska, K. (2018). Application of semipermeable membrane devices for long-term monitoring of polycyclic aromatic hydrocarbons at various stages of drinking water treatment. Science of the Total Environment, 631, 1431-1439. https://doi.org/10.1016/j.scitotenv.2018.03.105

Pretorius, T. R., Charest, C., Kimpe, L. E., \& Blais, J. M. (2018). The accumulation of metals, PAHs and alkyl PAHs in the roots of Echinacea purpurea. PloS One, 13(12), e0208325. https://doi.org/10.1371/journal.pone.0208325

Ramel, F., Birtic, S., Cuiné, S., Triantaphylidès, C., Ravanat, J. L., \& Havaux, M. (2012). Chemical quenching of singlet oxygen by carotenoids in plants. Plant Physiology, 158(3), 1267-1278. https://doi.org/10.1104/pp.111.182394

Reynoso-Cuevas, L., Gallegos-Martínez, M. E., Cruz-Sosa, F., \& Gutiérrez-Rojas, M. (2008). In vitro evaluation of germination and growth of five plant species on medium supplemented with hydrocarbons associated with contaminated soils. Bioresource Technology, 99(14), 6379-6385. https:// doi.org/10.1016/j.biortech.2007.11.074

Sabir, P., Ashraf, M., \& Akram, N. A. (2011). Accession variation for salt tolerance in proso millet (Panicum miliaceum L.) using leaf proline content and activities of some key antioxidant enzymes. Journal of Agronomy and Crop Science, 197(5), 340-347. https://doi.org/10.1111/j.1439037X.2011.00471.X

Salehi-Lisar, S. Y., \& Deljoo, S. (2015). Physiological effect of phenanthrene on Triticum aestivum, He Ha nth us annus and Medicago sativa. EurAsian Journal of BioSciences, 9(1), 29-37. https://doi.org/10.5053/ejobios.2015.9.0.4

Singh-Tomar, R., \& Jajoo, A. (2013). Alteration in PS II heterogeneity under the influence of polycyclic aromatic hydrocarbon (fluoranthene) in wheat leaves (Triticum aestivum). Plant Science, 209, 58-63. https://doi.org/10.1016/j. plantsci.2013.04.007
Singleton, V. L., Orthofer, R., \& Lamuela-Raventós, R. M. (1999). [14] Analysis of total phenols and other oxidation substrates and antioxidants by means of folin-ciocalteu reagent. Methods in Enzymology, 299, 152-178. https://doi. org/10.1016/S0076-6879(99)99017-1

Smith, M. J., Lethbridge, G., \& Burns, R. G. (1997). Bioavailability and biodegradation of polycyclic aromatic hydrocarbons in soils. FEMS Microbiology Letters, 152(1), 141-147. https://doi.org/10.1111/j.1574-6968.1997.tb10420.x

Somtrakoon, K., \& Chouychai, W. (2013). Phytotoxicity of single and combined polycyclic aromatic hydrocarbons toward economic crops. Russian Journal of Plant Physiology, 60(1), 139-148. https://doi.org/10.1134/S1021443712060155

Sverdrup, L. E., Krogh, P. H., Nielsen, T., Kjær, C., \& Stenersen, J. (2003). Toxicity of eight polycyclic aromatic compounds to red clover (Trifolium pratense), ryegrass (Lolium perenne), and mustard (Sinapsis alba). Chemosphere, 53(8), 993-1003. https://doi.org/10.1016/S0045-6535(03)00584-8

Tian, L., Yin, S., Ma, Y., Kang, H., Zhang, X., Tan, H., ... \& Liu, C. (2019). Impact factor assessment of the uptake and accumulation of polycyclic aromatic hydrocarbons by plant leaves: Morphological characteristics have the greatest impact. Science of the Total Environment, 652, 1149-1155. https://doi.org/10.1016/j.scitotenv.2018.10.357

Tomar, R. S., \& Jajoo, A. (2014). Fluoranthene, a polycyclic aromatic hydrocarbon, inhibits light as well as dark reactions of photosynthesis in wheat (Triticum aestivum). Ecotoxicology and Environmental Safety, 109, 110-115. https://doi. org/10.1016/j.ecoenv.2014.08.009

Wei, H., Song, S., Tian, H., \& Liu, T. (2014). Effects of phenanthrene on seed germination and some physiological activities of wheat seedling. Comptes Rendus Biologies, 337(2), 95-100. https://doi.org/10.1016/j.crvi.2013.11.005

Wiłkomirski, B., Jabbarov, Z. A., Abdrakhmanov, T. A., Vokhidova, M. B., Jabborov, B. T., Fakhrutdinova, M. F., ... \& Abdullayeva, Y. D. (2018). Polycyclic Aromatic Hydrocarbons (PAHs) in Natural and Anthropogenically Modified Soils (A Review). Biogeosystem Technique, (5), 229-243. https:// doi.org/10.13187/bgt.2018.2.229

Wilcke, W., Müller, S., Kanchanakool, N., Niamskul, C., \& Zech, W. (1999). Polycyclic aromatic hydrocarbons in hydromorphic soils of the tropical metropolis Bangkok. Geoderma, 91(3-4), 297-309. https://doi.org/10.1016/S00167061(99)00012-9

Winterbourn, C. C., McGrath, B. M., \& Carrell, R. W. (1976). Reactions involving superoxide and normal and unstable haemoglobins. Biochemical Journal, 155(3), 493-502. https://doi.org/10.1042/bj1550493 